\title{
Expandir as escolas, aumentar a frequência, valorizar a agricultura: Celeste Gobbato e a educação municipal (Caxias do Sul, RS, 1924-1928)
}

Expanding schools, increasing attendance, valuing agriculture: Celeste Gobbato and municipal education (Caxias do Sul, RS, 1924-1928)

Expandir las escuelas, aumentar la frecuencia, valorar la agricultura: Celeste Gobbato y la educación municipal (Caxias do Sul, RS, 1924-1928)

Terciane Ângela Luchese ${ }^{1}$

\section{Resumo}

O presente artigo analisa a administração de Celeste Gobbato no município de Caxias nos anos de 1924 a 1928. Gobbato imigrou da Itália contratado pelo governo estadual para atuar na Escola de Engenharia de Porto Alegre como professor. Com formação superior e doutorado em Ciências Agrárias, para além de sua atuação marcante no campo da vitivinicultura e da docência, foi indicado e assumiu a intendência de Caxias na década de 1920. Chegou ao poder em nome da conciliação política e elegeu como um dos pontos prioritários a escolarização. Sua gestão foi marcante seja pela expansão das escolas municipais e investimento no ensino rural, seja pela construção e abertura do Patronato Agrícola. $\mathrm{O}$ artigo procura evidenciar as estratégias colocadas em jogo para a promoção da escolarização no período de sua gestão que intentou expandir a oferta, aumentar a frequência e melhorar o ensino rural.

Palavras-chave: Educação municipal. Ensino rural. Patronato agrícola.

\footnotetext{
${ }^{1}$ Doutorado em Educação pela Universidade do Vale do Rio dos Sinos. Professora da Universidade de Caxias do Sul no Programa de Pós-Graduação em Educação e no Programa de Pós-Graduação em História. Bolsista de Produtividade em Pesquisa do CNPq. E-mail: taluches@ucs.br
} 


\begin{abstract}
This article analyzes the management of Celeste Gobbato in the municipality of Caxias from 1924 to 1928 . Gobbato immigrated from Italy hired by the state government to work at the School of Engineering of Porto Alegre as a professor. He had a PhD degree in Agrarian Sciences and outstanding performance in the field of viticulture and was appointed and took over Caxias' administration in the 1920s. He came to power in the name of political conciliation and elected education as one of his targets. His management was marked by the expansion of municipal schools and investment in rural education by the construction and opening of the Agricultural Patronage. The article seeks to highlight the strategies put in place for the promotion of education during the period of his management that sought to expand the number of schools, increase attendance and improve rural education.
\end{abstract}

Keywords: Municipal education. Rural education. Agricultural Patronage.

\title{
Resumen
}

El presente artículo analiza la gestión de Celeste Gobbato en el municipio de Caxias entre los años 1924 a 1928. Gobbato inmigró de Italia contratado por el gobierno estadual para actuar en la Escuela de Ingeniería de Porto Alegre como profesor. Con formación superior y doctorado en Ciencias Agrarias, más allá de su actuación marchante en el campo de la vitivinicultura y de la docencia, fue indicado y asumió la intendencia de Caxias en la década de 1920. Llegó al poder en nombre de la conciliación política y eligió como uno de los puntos prioritarios la escolarización. Su gestión fue marcante sea por la expansión de las escuelas municipales e inversión en la educación rural, sea por la construcción y apertura del Patronato Agrícola. El artículo procura evidenciar las estrategias puestas en juego para la promoción de la escolarización en el período de su gestión que intentó expandir la oferta, aumentar la frecuencia y mejorar la educación rural.

Palabras clave: Educación municipal. Educación rural. Patronato agrícola. 
a cidade não conta o seu passado, ela o contém como as linhas da mão, escrito nos ângulos das ruas, nas grades das janelas, nos corrimões das escadas, nas antenas dos páraraios, nos mastros das bandeiras, cada segmento riscado por arranhões, serradelas, entalhes, esfoladuras.

(CALVINO, 2003, p. 16).

\section{Considerações iniciais}

Perscrutar, no tempo em que vivemos, o passado inscrito na materialidade das cidades como inspira Calvino (2003) na epígrafe de abertura, significa atentar para os "arranhões, serradelas, entalhes, esfoladuras" que sinalizam o tempo que foi, o vivido inscrito nas marcas do presente, os pormenores, ou mesmo os detritos e refugos pretéritos (Ginzburg, 1989). O presente artigo analisa o período administrativo do intendente italiano de Caxias $^{2}$, Celeste Gobbato $^{3}$. Ele imigrou da Itália contratado pelo governo gaúcho para atuar na Escola de Engenharia de Porto Alegre como professor. Com formação superior e doutorado em Ciências Agrárias, para além de sua atuação marcante no campo da vitivinicultura e da docência, foi indicado e assumiu a intendência de Caxias na década de 1920 como um nome de conciliação.

Caxias foi colonizada por uma maioria de imigrantes saídos da península itálica no segundo quartel do século XIX e elevada à condição de município em 1890, tendo como intendentes, nomeados e/ou eleitos, representantes do Partido Republicano Riograndense (PRR), muitas vezes com candidatos únicos, mas que tinham enfrentado ao assumirem o poder político local, muitas tensões e conflitos em diversos momentos conflituosos. Esses conflitos tinham sido tensionados ainda mais com a Revolução de $1923^{4}$, assim "com o apoio do clero local, Gobbato representaria o elemento de interseção capaz se atenuar o avanço das oposições assisistas e romper com o poder luso local. A esfera da sociedade civil e do poder políticoadministrativo falariam a mesma língua" (RELA, 2004, p. 75).

\footnotetext{
${ }^{2}$ O acréscimo da posição geográfica “do Sul” foi determinado pelo Decreto no 720 de 29 de dezembro de 1944, ficando o município com a atual denominação Caxias do Sul.

${ }^{3}$ A biografia de Celeste Gobbato foi tema da tese de Katani Monteiro publicada em 2016 sob o título Entre o vinho e a política: uma biografia de Celeste Gobbato (1890 - 1958). Conforme a autora "O ano era 1912 e Celeste Gobbato tinha 22 anos de idade, quando embarcou no navio francês Plata, para realizar uma viagem que duraria 29 dias até o seu destino final: o lago Guaíba, em Porto Alegre. A partida deu-se em Gênova [...] Ele nasceu em Volpago del Montello, cidade tipicamente agrícola, em 1890. [...] Pelo que se sabe de seus pais, Pedro Gobbato e Anna Agnoletti, eram pequenos proprietários rurais em Volpago, e a produção de suas terras abastecia o mercado local e garantia o sustento da família, que era formada ainda por mais três irmãos. De todos eles, apenas Celeste mudou de país. [...] Gobbato formou-se enólogo-viticultor na Reale Scuola di Viticoltura ed Enologia di Conegliano aos 17 anos de idade e aos 21 anos obteve o diploma de agrônomo na Università di Pisa, onde realizou o doutoramento em Ciências Agrárias" (MONTEIRO, 2016, p. 25 - 27). Celeste Gobbato e Berta Schwemmer se conheceram no navio, no retorno de Gobbato da Itália em 1920 e "casaram-se em Porto Alegre e tiveram quatro filhos: Mario Pedro Ângelo, falecido em 1982, nasceu na capital gaúcha e formou-se em Medicina; Tito Alberto escolheu a química industrial como profissão; Lydia Anna optou pelo magistério das Ciências Naturais e hoje é professora aposentada e Piero Ludovico seguiu a carreira militar. Os três últimos nasceram em Caxias e, desde 1937, quando o pai deixou a direção da Estação Experimental de Viticultura e Enologia e a família retornou a Porto Alegre [...]" (MONTEIRO, 2016, p. 32).

${ }^{4}$ É importante lembrar que em 1923 o Rio Grande do Sul passou por uma Revolução que envolveu os partidários republicanos aliados do presidente do estado, Antônio Augusto Borges de Medeiros de um lado e de outro, os que apoiavam o federalista Joaquim Francisco de Assis Brasil. A revolução cessou com a assinatura do Acordo de Pedras Altas que estabelecia a permanência de Borges de Medeiros até o fim de seu mandato, mas a proibição da reeleição. Os rebeldes foram anistiados e a eleição do vice-presidente passou a ser feita também pelo voto. Conforme estudo de Rela (2004) as tensões decorrentes da Revolução de 1923 agitou Caxias, tensionada ainda mais do que o restante do Rio Grande do Sul pela força local da Igreja Católica. Por isso, o nome de Celeste Gobbato foi o nome da conciliação política.
} 
Gobbato chegou ao poder em nome da conciliação política e elegeu como um dos pontos prioritários de sua gestão, a escolarização. Seu período administrativo foi marcante pela expansão das escolas municipais e investimento no ensino rural, bem como pela construção e abertura do Patronato Agrícola. O presente artigo procura evidenciar as estratégias colocadas em jogo para a promoção da escolarização no período de sua gestão que intentou expandir a oferta, aumentar a frequência e melhorar o ensino rural. Os documentos mobilizados foram livros de atas, inclusive do Conselho Municipal, fotografias, jornais, relatórios dos intendentes, correspondências, documentações escolares e entrevistas tomadas a partir da análise documental histórica. O olhar para o município objetivou também fazer o jogo de escalas como pensa Revel (1998, p. 13), considerando "as migalhas de informações" e tentando "compreender de que maneira este detalhe individual, aqueles retalhos de experiências dão acesso a lógicas sociais e simbólicas que são as lógicas do grupo, ou mesmo de conjuntos maiores". O texto está organizado em dois movimentos: num primeiro analisa a administração de Gobbato e sua ação em prol da escolarização e no segundo, atenta para a fundação do Patronato Agrícola.

\section{1 - As escolas municipais: expansão da oferta e incremento na frequência}

A década de 1920 sinalizava transformações importantes para Caxias e região. As famílias cresciam e parte delas suscitavam novas migrações para o noroeste do estado do Rio Grande do Sul, além do oeste de Santa Catarina e Paraná, buscando mais terras e novas frentes de ocupação. Intensificaram-se também as migrações da área rural para a urbana, com crescimento da industrialização incentivada com a Primeira Guerra. Atente-se para o quadro 1, observando o percentual de crescimento da população urbana em Caxias:

Quadro 1 - População urbana de Caxias

\begin{tabular}{|c|c|c|c|}
\hline Anos & População total & População urbana & \% \\
\hline 1900 & 24.997 & 2.500 & 10,1 \\
\hline 1910 & 23.965 & 3.742 & 15,6 \\
\hline 1920 & 33.773 & 7.500 & 22,2 \\
\hline 1930 & 32.622 & 9.975 & 30,57 \\
\hline 1940 & 39.500 & 20.123 & 50,9 \\
\hline 1950 & 59.533 & 36.742 & 61,7 \\
\hline
\end{tabular}

Fonte: Machado, 2001, p. 211.

O crescimento urbano registrado nos anos 1920, no pós-Primeira Guerra está associado ao avanço da industrialização e da atividade comercial. As condições financeiras assumidas por Gobbato como Intendente de Caxias não eram nada lisonjeiras em 1924, pois segundo Machado (2001, p. 211) o "novo intendente encontrou Caxias com uma infraestrutura deficiente de estradas, de abastecimento de água e de energia elétrica, entre outras necessidades como nas áreas de saúde e da educação". No entanto, isso não refreou suas iniciativas.

Uma das primeiras ações com a tomada de posse aos 12 de outubro de 1924 foi a criação da fundação Pró-Caxias em fins de novembro daquele mesmo ano e permaneceu até o final da sua administração. "A forma de trabalho foi centrada nos estudos promovidos em cada uma das subcomissões, reunindo-se a seguir, a grande comissão Pró-Caxias que, em sessão aberta, discutia o resultado dos mesmos" (RELA, 2004, p. 81) e essa conjunção reuniu forças de apoio ao recém empossado intendente que o legitimaram e o sustentaram ao longo de seu governo. Gobbato não administrou simplesmente com o PRR como habitualmente ocorria, mas foi respaldado pela Igreja Católica que exercia considerável poder local, representantes das 
associações católicas leigas, por grandes industrialistas como Aristides Germani e Abramo Eberle, que também era vice-intendente. É, também, na sua administração que a valorização do italiano e um enaltecimento do "colono" ganham força nas representações do processo identitário regional, em especial com o marco das celebrações do Cinquentenário de Imigração Italiana para o RS. Demarcou também uma aproximação com o poder político italiano, representado por seus cônsules e o fascismo ${ }^{5}$.

Dentre o conjunto de mudanças que Caxias vivenciou durante o período administrativo de Gobbato temos: (1) novas instalações da hidráulica municipal que ampliou e melhorou substantivamente a distribuição de água potável; (2) melhorias no matadouro público; (3) remodelação das ruas com calçadas e macadamização na área urbana; (4) abertura e melhorias de estradas na área rural, com construção de pontes e pontilhões; (5) ampliação do recolhimento de lixo e cabungos, que se tornou diário na área central; (6) criou a Inspetoria Agrícola com o fim de fomentar a agricultura; (7) reformou a Inspetoria de Limpeza Pública e contratou varredores de rua; (8) melhorias na iluminação pública, que em 1927 tinha 121 lâmpadas e 12.500 velas; (9) preocupou-se com transporte público, com "auto-ônibus". Também criou a Caixa Econômica Municipal onde os habitantes depositavam suas economias para serem aplicadas no desenvolvimento local. Gobbato foi representado pelos jornais locais como incansável, como 'grande intendente e administrador' tendo dado atenção, como conhecedor das questões agrícolas e de vitivinicultura, pela sua profissão e formação, às áreas rurais do município e à escolarização.

No que tange à escolarização municipal, uma das primeiras medidas foi a criação da Inspetoria Escolar que tinha como finalidade a organização, a preparação dos quadros administrativos e o acompanhamento dos professores municipais, ficando o Inspetor Escolar municipal incumbido de, textualmente, conforme o Ato $\mathrm{n}^{\circ} 27$, de 01 de julho de 1925:

Ato $\mathrm{n}^{\circ} 27$

Capítulo IV.

Art. 16 - Ao Inspetor Escolar compete:

a) Visitar com a possível assiduidade, as escolas municipais lavrando no respectivo livro a ata da inspeção.

b) Fazer cumprir o programa de ensino e indicar os livros que deverão ser adotados.

c) Observar tudo o que possa interessar a instrução municipal dando disso ciência ao Intendente.

d) Organizar o livro de matricula dos alunos de todas as escolas municipais.

e) Realizar por si e pelos professores municipais preleções nas escolas, principalmente nas datas nacionais.

f) Procurar pelos meios adequados fomentar a instrução primária, principalmente na zona rural.

g) Organizar mensalmente a folha de pagamentos relativa ao pessoal da Instrução Pública Municipal.

h) Fiscalizar as aulas particulares subvencionadas pela intendência. [...] (REGISTROS DE Atos..., 1924 - 1930).

Articulado com o governo estadual de Borges de Medeiros, Gobbato imprimiu importantes mudanças nas escolas municipais. Como afirmam Carvalho e Carvalho (2010, p. 02), Gobbato manifesta em suas ações a "crença no poder regenerador da educação e da difusão dos sistemas escolares" sendo parte central das "elites locais [que] fazem uso desse processo para a definição de uma identidade municipal e para a defesa de objetivos particulares". Com

\footnotetext{
${ }^{5}$ Sobre o tema ver Giron (2017).
} 
relação a escolarização municipal diversas estratégias foram postas em ação, destacando-se a preocupação com a frequência escolar, com a localização e as condições materiais das escolas, bem como com a expansão da oferta. Sob o título 'I lavori della nuova amministrazione di Caxias' [Os trabalhos da nova administração em Caxias] o jornal Correio Colonial afirmava em início de março de 1925, com relação aos 'avanços' na educação:

Figura 1 - Recorte notícia jornalística sobre escolas em Caxias, $1925^{6}$

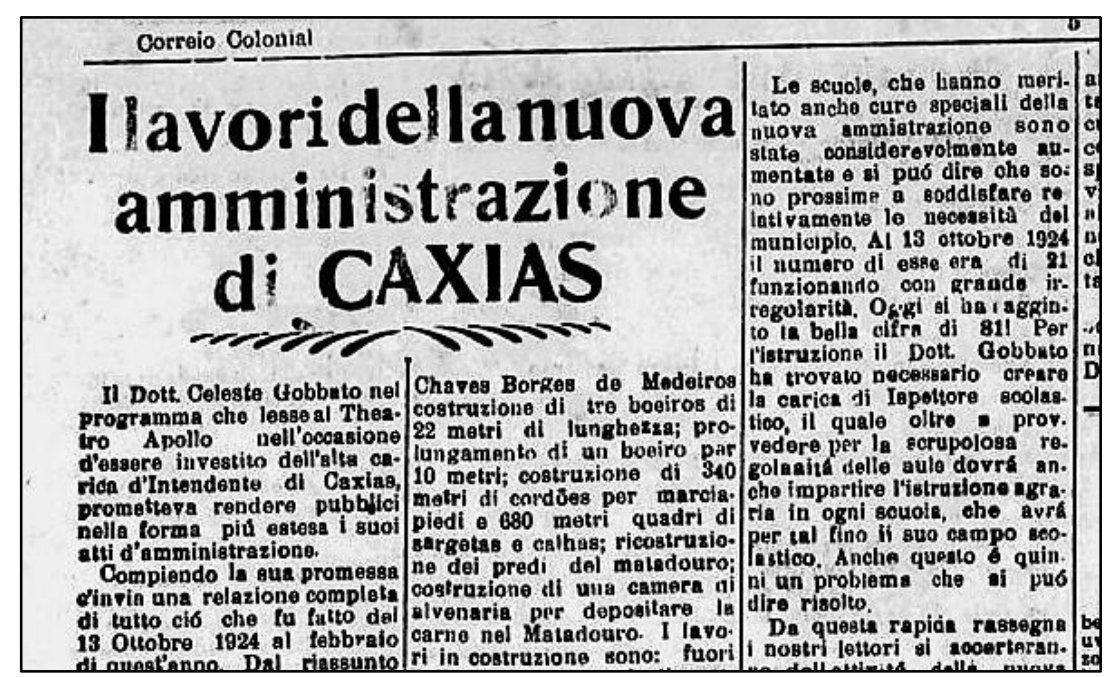

Fonte: Jornal Correio Colonial, 07/03/1925, p. 05.

O que já em março de 1925 se noticiava como 'resolvido' demandaria ainda ajustes e atenção por parte do poder público municipal. Esse foi um período em que a municipalidade recebeu diversas transferências de terrenos com prédios escolares e seu mobiliário, pertencentes às comunidades locais (Luchese 2012, 2015) o que demonstra o apreço que Gobbato tinha nas áreas rurais. Além disso, Gobbato percorreu as comunidades rurais, averiguando as necessidades e fazendo levantamento de quais as melhores localizações para a instalação das escolas. Nesse aspecto, recebeu inúmeras demandas de famílias que justificavam o valor, a importância e as vantagens que obteriam com a abertura de uma escola. Para exemplificação, a seguir, uma das petições enviadas ao intendente:

\section{Ilmo Sr. Dr. Celeste Gobatto}

M. D. Intendente Municipal, de Caxias,

Os abaixo assinados moradores no travessão Portugal, São Valentim, $3^{\circ}$. Distrito deste município, pais de vários filhos e estando sem instrução alguma vem solicitar a V. S. se dignasse favorecê-los a esse respeito. $\mathrm{Na}$ espera, de V.S. serem favorecidos, sabendo que nunca poupou esforços para proteger a instrução.

Nestes termos pedem deferimento.

Caxias, 27 de agosto de 1927 (CORRESPONDÊNCIAS, códice 06.01.02).

6 Transcrição: As escolas, que tem merecido especial cuidado da nova administração, tendo sido consideravelmente aumentadas e se pode dizer, estão próximas de satisfazer relativamente a necessidade do município. Aos 13 de outubro de 1924 o número dessas, era de 21 funcionando com grande irregularidade. Hoje se alcançou a bela cifra de 81 ! Para a instrução o Dr. Gobbato achou necessário criar o cargo de Inspetor Escolar, o qual deve prover para a cuidadosa regularidade das aulas, deve transmitir a instrução agrária em cada escola, que terá para tal fim o seu campo escolar. Também esse é um problema de que se pode dizer resolvido. 
A petição foi assinada por 14 pais que apresentaram o número de 35 crianças que seriam beneficiadas. Como resposta, na correspondência está o registro do Inspetor Escolar, Salvador Petrucci, em 08 de outubro de 1927, afirmando que "Penso que conquanto se justifique a pretensão dos requerentes, relativamente à instalação de escola, o assunto deveria ser tratado no próximo ano letivo". Já o Intendente Gobbato, na mesma data registrou "Os requerentes construindo a casa e fazendo doação da mesma e de um pedaço de terra a municipalidade será instalada a aula pedida". A posição do Intendente, incentivando as comunidades a participarem com a construção do prédio para abrigar a escola e doando-o, juntamente com o terreno, à municipalidade foi uma estratégia recorrente e permitiu a ampliação da rede escolar municipal. De toda forma, no registro das aulas municipais de 1928 consta que a comunidade recebeu uma escola e a professora nomeada foi Irma Roglio (RELATÓRIO, 1928b, p. 92).

Uma das preocupações constantes foi a frequência escolar e o debate intentava estabelecer a linha de ação mais promissora para resolver o problema no município. Que estratégia implementar para que a frequência escolar pudesse ser ampliada? Em seu relatório, Gobbato considerava que era necessário ter flexibilidade no calendário escolar por que "se o menor retirado da escola durante os períodos de trabalho na colônia sofre o prejuízo da falta de instrução de letras, temporariamente, aproveita a prática salutar dos trabalhos da terra, não ficando completamente alheio aos mesmos e até aperfeiçoando-se" (RELATÓRIO, 1926, p. 53). Para Gobbato o trabalho rural que as crianças faziam também era tomado como educativo e necessário, no entanto, não poderia prejudicar a frequência escolar. Em publicação no jornal O Regional, de março de 1927, o Inspetor Salvador Petrucci comunicava aos professores municipais a necessária interrupção nas aulas por conta da vindima:

Aulas Municipais. Lembro os Srs. Professores e Professoras Municipais que durante o mês de março e princípio de abril serão concedidos 15 dias de férias por ocasião dos trabalhos de vindima. Essas férias que visam o aproveitamento dos alunos nos trabalhos de colheita de uva, só serão concedidas nas escolas localizadas nas zonas vinícolas, ouvida a opinião dos interessados quanto à época. Salvador Petrucci. Inspetor Escolar (JORNAL 'O Regional', 27/03/1927, capa).

Assim, orientava para que os professores tivessem bom senso na organização do calendário. Mas a principal medida para garantir a manutenção da frequência escolar foi a criação do estímulo financeiro para apoiar as famílias que enviassem os filhos para a escola. Pela Lei ${ }^{\circ}$ 61, artigo $3^{\circ}$, em seu Parágrafo 20, foi autorizado pagar uma gratificação aos pais das famílias no valor de "5\$000 para cada filho que tiver matriculado nas escolas municipais, dentro das condições regulamentares [...], o que ocasionou um aumento considerável na frequência, tendo sido beneficiados 589 chefes de família, com 5:870.000, correspondente a 1174 alunos" informava o Intendente (RELATÓRIO, 1928, p. 47). Nem todos os dados puderam ser auferidos para perceber o impacto efetivo dessa lei, mas o crescimento no período foi relevante atingindo $80 \%$ das crianças em idade escolar e que a frequentavam com regularidade, conforme quadro 2 : 
Quadro 2 - Frequência dos estudantes em Caxias

\begin{tabular}{|c|c|c|c|c|c|}
\hline \multicolumn{2}{|c|}{1925} & \multicolumn{2}{c|}{1926} & \multicolumn{2}{c|}{1927} \\
\hline Matriculados & Frequentes & Matriculados & Frequentes & Matriculados & Frequentes \\
\hline 5350 & 4014 & 5427 & 5602 & 4351 & - \\
\hline
\end{tabular}

Fonte: RELATÓRIO, 1926, 1928, 1928a, 1928b.

Atentando para os dados separadamente, por diferentes tipologias de instituições escolares, conforme o quadro 3, se percebe que a maior frequência e número de escolas está naquelas escolas isoladas mantidas em áreas rurais pelo município. Se o ano de 1925 for considerado como referência, já que os dados estão completos, a relação entre alunos matriculados e frequentes atinge uma média de $78 \%$, sendo menor no Colégio Elementar $(69,85 \%)$, conforme o quadro 3 :

Quadro 3 - Matrícula e frequência em Caxias

\begin{tabular}{|c|c|c|c|c|c|c|c|c|c|c|}
\hline \multirow{2}{*}{ Ano } & \multicolumn{2}{|c|}{$\begin{array}{c}\text { Escolas } \\
\text { municipais }\end{array}$} & \multicolumn{2}{c|}{$\begin{array}{c}\text { Escolas } \\
\text { estaduais } \\
\text { isoladas }\end{array}$} & \multicolumn{2}{c|}{$\begin{array}{c}\text { Escolas } \\
\text { paroquiais e } \\
\text { religiosas }\end{array}$} & \multicolumn{2}{c|}{$\begin{array}{c}\text { Colégio } \\
\text { Elementar }^{8}\end{array}$} & \multicolumn{2}{c|}{$\begin{array}{c}\text { Escolas } \\
\text { particulares }\end{array}$} \\
\cline { 2 - 12 } & Matr. & Freq. & Matr. & Freq. & Matr. & Freq. & Matr. & Freq. & Matr. & Freq. \\
\hline 1925 & 2896 & 2258 & 495 & 357 & 1422 & 1107 & 355 & 248 & 152 & 120 \\
\hline 1926 & 2901 & 2257 & 617 & 457 & 1553 & 1406 & 356 & 265 & - & - \\
\hline 1927 & 3002 & 2171 & 536 & 346 & 1576 & 1434 & 425 & 351 & - & - \\
\hline
\end{tabular}

Fonte: RELATÓRIO, 1926, 1928, 1928a, 1928b.

Em 1927 algumas escolas rurais passaram a funcionar em dois turnos, diminuindo o tamanho das turmas, ampliando os ganhos dos professores e melhorando as condições de ensino, informou Gobbato. A ampliação do acesso, diminuindo as distâncias a serem percorridas para a ida à escola foi importante nesse período. Pelas informações auferidas no quadro 4, o número de escolas cresceu consideravelmente na década de 1920, sendo que a informação constante nos relatórios é de que todas estavam em funcionamento:

Quadro 4 - Escolas em Caxias

\begin{tabular}{|c|c|c|c|c|c|}
\hline Ano & $\begin{array}{c}\text { Escolas } \\
\text { municipais }\end{array}$ & $\begin{array}{c}\text { Escolas } \\
\text { estaduais } \\
\text { isoladas }\end{array}$ & $\begin{array}{c}\text { Escolas } \\
\text { paroquiais e } \\
\text { religiosas }\end{array}$ & $\begin{array}{c}\text { Colégio } \\
\text { Elementar }\end{array}$ & $\begin{array}{c}\text { Escolas } \\
\text { particulares }\end{array}$ \\
\hline 1923 & 21 & 43 & 4 & 1 & Sem dados \\
\hline 1925 & 78 & 11 & 15 & 1 & 5 \\
\hline 1926 & 86 & 13 & 15 & 2 & 5 \\
\hline 1927 & 88 & 11 & 12 & 2 & 6 \\
\hline 1928 & 79 & 10 & 12 & 1 & 5 \\
\hline
\end{tabular}

Fonte: RELATÓRIO, 1924, 1926, 1928, 1928a, 1928b.

Uma outra iniciativa foi a abertura de uma aula no prédio da Intendência para ensinar 'menores desvalidos' e 'engraxates', e, em horário separado, atender 'praças' da Guarda Municipal. Conforme indicado no Relatório (1926) também os presos recolhidos na cadeia podiam frequentar essa aula. Outra escola aberta em 1925, denominada Escola 'Conselho

\footnotetext{
${ }^{7}$ Estão contabilizadas as escolas subvencionadas pelo estado.

8 A partir de 1927 foi criado e instalado um Grupo Escolar Rural em Nova Vicenza (hoje município de Farroupilha).

${ }^{9}$ A partir de 1927 foi criado e instalado um Grupo Escolar Rural em Nova Vicenza (hoje município de Farroupilha). Sobre essa escolar ver FERNANDES (2015).
} 
Municipal ${ }^{10}$, era mantida com a doação dos estipêndios dos conselheiros municipais e voltada para o ensino das práticas comerciais, funcionando à noite. Conforme o Relatório de 1926 (1928, p. 47) era "destinada a proporcionar o ensino gratuito de português, aritmética, escrituração e correspondência comercial aos operários e pessoas adultas, de ambos os sexos". Dentre outras providências tomadas pela administração municipal estava a uniformização dos livros utilizados nas escolas municipais com o uso da Cartilha Maternal de João de Deus e o livro Noções de Aritmética de G.N., mencionando que o programa primava pela 'simplicidade', "banindo-se os programas vistosos com os compêndios abstratos, enfadonhos, sibilinos, para uma idade em que as noções concretas, miúdas, simples, são as únicas possíveis (Afrânio Peixoto, Pestalozzi)" (RELATÓRIO, 1926, p. 52). No intuito de facilitar a compra dos livros pelos pais, a Intendência tinha adquirido diretamente da editora uma soma considerável de livros que eram revendidos às famílias a preço de custo. Ainda, com relação às melhorias, foi localizado que "as aulas municipais todas estão servidas de mapas geográficos do Brasil e Rio Grande do Sul, quadro da Bandeira Nacional e pequenos quadros com noções de higiene" (RELATÓRIO, 1928a, p. 103).

Em março de 1925 foi realizado concurso para a seleção de professores, conforme consta em notícia veiculada no Jornal Correio Colonial:

Concurso para candidatos a professores municipais. De ordem do Sr. Intendente, Dr. Celeste Gobbato, científico aos interessados que se acha aberta a inscrição para o concurso de professores ou professoras municipais a realizar-se em abril próximo. Quaisquer informações serão fornecidas nesta Intendência Municipal durante as horas de expediente. Caxias, 11 de março de 1925. Salvador Petrucci. Inspetor Agrícola e Escolar (JORNAL 'Correio Colonial', 14/03/1925, p.02).

O concurso, foi realizado, mas somente em julho daquele ano a normatização dos serviços municipais criada pelo Ato $n^{\circ} 27$, de 01 de julho de 1925, estabeleceria em seu Capítulo XIV que "Art. $35^{\circ}$ Os cargos de professores municipais serão providos por concurso tendo preferências empregados da Intendência que demonstrarem suas habilitações para exercê-lo. Art. $36^{\circ}$ Nenhum candidato será inscrito a concurso sem sujeitar-se previamente a inspeção de saúde.[...] (REGISTROS DE Atos..., 1924 - 1930). Ao longo de seu mandato, pela ampliação do número de escolas municipais, foram realizados diversos concursos, assim como foram ofertados, no período de férias, cursos de aperfeiçoamento aos professores. Tratando desse tema em seu Relatório, Gobbato afirmou que "o corpo de professores, melhorado nos seus vencimentos, com o estímulo louvável de receber, além do ordenado, uma gratificação proporcional à frequência, sente-se bem nas suas atribuições e tem correspondido à expectativa" e ainda, afirmava que "a seleção feita em princípios de nossa administração e que consistiu num exame geral, controlador das aptidões e competência" havia sido fundamental para a qualificação do corpo docente (RELATÓRIO, 1926, p.51).

\footnotetext{
10 "Ilmo Sr. Dr. Celeste Gobatto, muito digno Intendente de Caxias, O requerente, abaixo assinado, ciente dos humanitários sentimentos que ornam V. S. vem submeter a Sua bondade o projeto de abertura de uma aula noturna para cursos primário e secundário a funcional numa das escolas do Colégio N. S. do Carmo. Devido à escassa remuneração dos alunos, pois que, visa este curso o mundo operário, suplica o pedinte uma subvenção da benemérita intendência municipal. Com alta estima, Caxias, 11 de julho de 1924. Vico P. Thompson." O resultado do pedido aparece como: "Deferido de acordo com a informação. A subvenção será fixada em $120 \$ 000$ mensais e a escola deverá denominar-se "Aula Conselho Municipal de Caxias". 25/7/1924. Celeste Gobatto." CORRESPONDÊNCIAS, códice 06.01.03).
} 
A professora Paulina Soldatelli Moretto ${ }^{11}$ em entrevista narrou as condições em que realizou o concurso para professora pública municipal em Caxias rememorando que estudara inicialmente com o professor João Fontana e depois com João Chemello. Algum tempo depois, com a chegada das Irmãs em São Marcos passou a frequentar a escola das Irmãs, tendo estudado seis anos, pois no sétimo ano "eu só ia no colégio aos domingos. Nos dias de semana eu trabalha em casa, ia na roça, se descansava um pouco, eu estudava, preparava os temas. Aos domingos eu ia na missa e depois ia no colégio. As irmãs, até o meio-dia, me davam um pouco de assistência, de atendimento, recebiam meus temas e valeu por um ano de aula" (MORETTO, 1983). Ao ser questionada sobre como se tornou professora ${ }^{12}$ ela contou que foi por necessidade da própria comunidade e por indicação das Irmãs, em suas palavras:

Com 14 anos eu comecei a lecionar como professora municipal, na Linha Zambicária, de S. Marcos. Eu era uma professora que sabia muito pouco. Mas como a escola estava fechada por falta de professores, os moradores daquela Linha, foram pedir para o subprefeito de S. Marcos, como eles poderiam conseguir uma professora. Ele disse que não tinha ninguém que fosse professora, que pudesse lecionar, mas sugeriu ir no Colégio das irmãs, que elas podiam indicar. A pessoa mais indicada, que sabia melhor, mais adiantada se dizia naquele tempo. E as irmãs me indicaram. Foram falar com meu pai e ele concordou. Comecei a lecionar lá na Linha Zambecária com 14 anos incompletos. Lecionei 8 anos. Depois interrompi porque casei e vim morar em Caxias, na cidade. Casei com Isidoro Domingos Moretto.

Paulina deixou a docência após o casamento, mas narrou em detalhes o cotidiano escolar na área rural ao longo dos oito anos que atuou:

Quando eu era professora, caminhava duas horas por dia, a pé, porque dava aula de manhã e de tarde. Aonde eu ia de manhã, a estrada era melhor, então podia fazer crochê caminhando. Muitas vezes, na volta, rezava o terço. Na outra parte, onde eu dava aula de tarde, a estrada era muito ruim, porque eram arrastadas as toras para o engenho, era estrada de mato. Lá não dava para se distrair, fazer crochê. Lecionava de manhã, de tarde e de noite dava aula para os adultos em Pedras Brancas. Eu parava numa casa de família em Pedras Brancas, e nunca paguei nada de pensão, porque aquela família, onde eu morava, aquele senhor era analfabeto. Ele tinha um sentimento de ser analfabeto, e dizia que queria uma professora para lecionar aqui na nossa comunidade: eu quero sempre hospedar na minha casa e não quero cobrar nada. Desde de que tenha uma professora para que os meus filhos possam estudar e que não fiquem analfabetos como eu. [...] fiquei 7 anos na casa dele e nunca paguei nada. Os filhos dele aprenderam a ler, escrever. Eram muito inteligentes. Inclusive os rapazes daquela vizinhança, vinham lá em casa de noite, porque tinham se alfabetizado comigo na escola e não podiam continuar, porque tinham que trabalhar na roça. Então vinham de noite. Eu dava aula lá. Não cobrava nada, não ganhava nada e também não pagava nada. Só que

11 Paulina Soldatelli nasceu aos 03 de junho de 1913, em São Marcos, Caxias, filha dos imigrantes José Soldatelli (proveniente de Mantova) e Rosa Pelizzer Soldatelli (proveniente de Treviso).

${ }^{12}$ Em correspondência ao Intendente Gobbato, a professor Paulina comunicou-se nos seguintes termos "Ilmo Sr. Dr. Celeste Gobato, Digníssimo Intendente Municipal de Caxias. Pela presente venho comunicar a V. S. que nesta data entrei em exercício do cargo de professora da aula localizada na Linha Zambecari, para o qual fui nomeada por portaria de 16 do corrente. Desnecessário será dizer a V. S. que farei tudo o que estiver ao meu alcance para bem desempenhar os deveres inerentes ao cargo, não poupando esforços no sentido de inculcar à juventude o temor de Deus fonte de toda a sabedoria e o amor à nossa Pátria - o Brasil e o respeito e obediência as autoridades constituídas. Sumamente agradecida, peço a V. S. aceitar os protestos de profundo respeito com que sou de V. S. Criada M. Att. Paulina Soldatelli. São Marcos, 19 de março de 1928” (CORRESPONDÊNCIAS, códice 06.01.03). 
a gente tinha que providenciar as velas, porque não tinha luz. Então não era justo que o Sr. Sandri pagasse o querosene. Então fazíamos as velas de cera, dentro dos canos de taquara. Cada um fazia um pouco e assim tínhamos as velas para usar de noite, dando aula na casa. A gente era capelã, catequista, ensinava a bordar, ensinava civilidade, bons modos, era conselheira nas famílias, tudo isso a professora tinha que fazer no interior. Inclusive assistir aquele que estava morrendo. Eu me lembro até um enterro, de um menino que eu fiz. Não tinha padre. Eu não sabia nem o que dizer, mas acompanhei e rezei o que sabia, quando levaram para o cemitério (MORETTO, 1983).

O acolhimento da professora pelas famílias, a valorização de seus saberes, o exercício de certa liderança na comunidade, muito além da atividade em aula, com tarefas vinculadas à catequese, ao aconselhamento e aos cuidados com a própria capela são as representações do 'bom professor'. Mesmo tendo se tornado professora de modo improvisado, Paulina representou a 'boa professora' pois como afirmam Luchese e Grazziotin (2015, p. 354) era necessário que

conseguisse ser exemplo de vida; que cumprisse os deveres, respeitando o tempo da aula, mantendo a disciplina, ensinando de forma conveniente as noções essenciais da leitura, da escrita e das operações fundamentais; que fosse capaz de organizar os alunos, com ordem, respeito e asseio, participando dos momentos de socialização, festividades e demais acontecimentos da comunidade; de bom caráter, que não tivesse vícios e preservasse os bons costumes.

E para isso, por vezes independia o tempo de estudo ou a qualidade da formação previamente para o exercício da docência. Nas áreas rurais o fazer docente era legitimado por esse conjunto de representações. E as comunidades que não encontrassem correspondência do desejável no professor nomeado, em geral, faziam petições e abaixo-assinados denunciando o professor e não enviando os filhos para a escola.

No que tange a administração municipal no período do Intendente Gobbato, outro acontecimento relevante foi o Congresso dos Intendentes dos municípios da região colonial do Estado. Realizado entre os dias 03 e 04 de maio de 1925, a proposta partiu de "uma palestra havida entre administradores de municípios coloniais italianos, ideia que foi aplaudida pelo nosso benemérito chefe, Dr. Borges de Medeiros, presidente do Estado" noticiava o Jornal "A Federação' (06/05/1925, p 03). Os pontos previamente estabelecidos para estudo, foram os seguintes:

a) Estudo e possível unificação das leis orçamentárias.

b) Exame para possível substituição do imposto da estatística e expediente para outra tributação equivalente.

c) Problema da viação rural e intermunicipal.

d) Ensino elementar e profissional.

e) Exame e eventual unificação dos códigos de postura municipais.

f) Criação de um viveiro intermunicipal e meios para fomentar a racional agricultura colonial.

g) Diversos outros assuntos de interesse comum.

Chama atenção que a escola - em especial a elementar e profissional estivessem no centro do debate. Os intendentes estavam convencidos de que poderiam administrar melhor seus municípios se construíssem soluções coletivas e fortalecessem estudos e projetos conjuntos. Os municípios convidados tiveram total adesão, com a presença do intendente e do representante do conselho municipal, conforme quadro 5: 
Quadro 5 - Municípios e seus representantes no Congresso

\begin{tabular}{|l|l|l|}
\hline \multicolumn{1}{|c|}{ Município } & \multicolumn{1}{c|}{ Intendente } & $\begin{array}{c}\text { Representante do Conselho } \\
\text { Municipal }\end{array}$ \\
\hline Caxias & Celeste Gobbato & Orestes Manfro \\
\hline Nova Trento & Joaquim Mascarello & Anselmo Carpeggiani \\
\hline Antônio Prado & Caetano Reginatto & Francesco Marcantonio \\
\hline Bento Gonçalves & João Baptista Pianca & Amadeu Arioli \\
\hline Encantado & Antonio de Conto & Victorio Costa \\
\hline Alfredo Chaves & Segismundo Reschke & Vitorio Dal Pai \\
\hline Garibaldi & Antonio Paganelli (representante) & Arduino D’ Arrigo \\
\hline Guaporé & Manoel Francisco Guerreiro & Alberto Morassutti \\
\hline Prata & Felix Engel Filho & Adolpho Schneider \\
\hline São Sebastião do Caí & Ernesto Noll & Carlos Oderich \\
\hline $\begin{array}{l}\text { São Francisco de Paula de } \\
\text { cima da Serra }\end{array}$ & Alfredo Lucena (representante) & \\
\hline
\end{tabular}

Fonte: organização da autora a partir dos dados do Jornal ‘A Federação', 06/05/1925, p. 02 e 03.

A esse grupo, reuniu-se o representante do governo, Renato Costa, que era diretor geral do Tesouro do Estado. Iniciadas as discussões e debates no dia 04 de maio, com relação à educação, os encaminhamentos, segundo noticiado no Jornal ‘A Federação' foram os seguintes:

Ensino elementar e profissional foi o ponto abordado a seguir, sendo nomeada em comissão os Drs. Celeste Gobbato e Feliz Engel Filho e o Sr. Manoel Francisco Guerreiro, que deverão organizar um programa e um regulamento de ensino para as aulas municipais e subvencionadas. E aprovada uma proposta do Dr. Gobbato para se solicite ao Governo do Estado a impressão ou aquisição por parte deste, de mapas geográficos e outros necessários ao ensino, fornecendo-os aos municípios pelo menor preço possível. Ainda por proposta do Dr. Gobbato é aprovada a anexação às escolas municipais de campos agrícolas onde serão ministrados ensinamentos práticos de agricultura, concorrendo destarte para o desenvolvimento da produção dessa zona. Todos os presentes se comprometeram a estabelecer em seus municípios os aludidos campos, devendo o Dr. Gobbato fornecer os modelos e programa a serem adotados oficialmente (JORNAL ‘A Federação', 06/05/1925, p. 03)

O Jornal 'Correio Colonial' noticiou praticamente o mesmo com relação aos encaminhamentos para a educação, mas acrescentou que "foi dado o encargo ao Dr. Pianca"13 para confeccionar um projeto de escola rural modelo, observando os preceitos de higiene, luz e conforto" (JORNAL 'Correio Colonial, 09/05/1925, p.02). Ainda, segundo esse jornal, os

13 "O engenheiro Dr. João Baptista Pianca, DD. Intendente Municipal de Bento Gonçalves no quatriênio 1924 - 1928, nasceu em Porto Alegre a 14 de julho de 1893, filho de José Pianca (oriundo de Treviso - Itália) e de D. Stella Facco de Padova. [...] Em 1915 obteve o título de engenheiro civil e em 1916 apresentou o projeto final, que lhe valeu o título de engenheiro. [...] em 1918, o Governo do Estado do Rio Grande do Sul abriu um concurso para o cargo de condutor das Obras Públicas. Nove foram os concorrentes que compareceram competentemente munidos dos documentos, entre os quais o Dr. Pianca, que logrou alcançar o primeiro lugar, no qual foi classificado e que lhe abriu de par em par, as portas da vida pública. Ao mesmo passo que entrava a trabalhar na Diretoria de Obras, projetou e dirigiu importantes trabalhos, tendo feito parte de importantes missões oficiais. Em 1919 foi nomeado professor de Arquitetura [...] foi ele eleito Intendente Municipal de Bento Gonçalves a 20 de setembro de 1924, assumindo o poder a 15 de novembro seguinte. Em consequência das suas novas funções, foi licenciado nas Obras Públicas e nas cadeiras da Escola de Engenharia. Uma vez empossado do cargo, o Dr. Pianca se inteirou, com um cuidadoso e exato exame das mais urgentes necessidades do município, organizado um vasto, complexo e ousado plano de reformas e obras novas, a cuja execução se votou [...]." (In: I Municipi della colonia italiana nello stato di Rio Grande do Sul (Brasile) - Bento Gonçalves - 1924 a 1928). 
intendentes decidiram seguir, em seus municípios, o regulamento estadual para as escolas. Cabe mencionar que o projeto de escola rural foi traçado e construído por Pianca, mas ficou reservado à Bento Gonçalves, conforme estudo de Luchese e Kreutz (2012).

As ações municipais em prol da escolarização no município de Caxias empreenderam diferentes ações para além daquelas aqui nominadas. Com Gobbato, o apoio às escolas particulares por parte do município, fornecendo subsídio anual, foi uma constante. As escolas paroquiais abertas sob os cuidados do pároco. Mons. Meneguzzi foram importantes polos de difusão da educação e da afirmação do catolicismo, sendo que todas contaram com algum apoio financeiro da Intendência. Uma síntese da instrução pública municipal foi publicada em julho de 1925 e assim se referia:

Instrução Pública. Um dos problemas essenciais que está sendo resolvido pelo Sr. Dr. Celeste Gobbato, Intendente deste município e que de antemão era conhecido, pois constava de sua magistral plataforma é o da instrução pública municipal. No estado de coisas e dificuldades financeiras em que encontrou o município, lhe era mister grandes esforços aliados à dedicação para desempenhar-se e levar a bom termo, resolvendo este tão útil quanto importante problema. Agindo com conhecimento de causa, percorreu o município em toda a sua extensão para poder conhecer as necessidades mais urgentes e localizar as aulas em pontos especiais que pudessem satisfazer as exigências do ensino. Em seguida, mandou proceder a um 'estágio' com o fim de que os atuais professores pudessem inteirar-se do regulamento em vigor a ao mesmo tempo submete-los a um suplementar exame. Deste modo conseguiu, com seu tino e competência, encaminhar essa importante questão, que é hoje um dos principais fatores do desenvolvimento econômico-social progressivo do Município. Presentemente o Município está dotado de 79 aulas municipais, além de outras que são subvencionadas pelo erário municipal e assim distribuídas: 7 aulas paroquiais, Colégio Nossa Senhora de Pompéia, em Ana Rech, Colégio Nossa Senhora de Lourdes, em Nova Vicenza, Colégio Juvenato São Carlos no Milanês e o de S. Miguel. Para a sua manutenção o Conselho Municipal votou a verba anual de 41:300\$000 que adicionada ao auxílio de Rs. 9:600\$000 que o Governo Estadual destinou para o ensino neste Município, perfez um total de 50:900\$000. Sendo a nossa receita orçada em Rs. 576:546\$948 anuais, depara-se que à instrução foi destinado aproximadamente 14,5\% da receita orçada. Um outro problema sobre instrução que mereceu especial cuidado de nosso Edil e que por sua inciativa foi amplamente tratado no Congresso dos Intendentes, realizado em maio último nesta cidade, é o campo agrícola escolar [...] (JORNAL 'Correio Colonial', 25/07/1925, p. 02) [grifos meus].

No ano seguinte, outra síntese foi publicada enfatizando os 'avanços' e as necessidades que ainda preocupavam a administração municipal no que se refere à escola.

Problemas municipais - Instrução Pública. [...] hoje nos ocuparemos da instrução pública, um dos principais pontos de que cuida nossa edilidade. Já se acham reabertas as aulas em todas as escolas públicas municipais, tendo os livros de matrícula acusado um número maior de inscrições do que no último ano. Este fato, verdadeiramente confortador, vem ao 
encontro dos esforços da atual administração do Município, que se tem dedicado com carinho ao problema do analfabetismo das nossas crianças. A Inspetoria Escolar, criada especialmente para atender o enorme movimento colegial do município, dirigida pelo nosso amigo Salvador Petrucci, tem sido incansável na fiscalização das aulas, tomando acertadas providências para que as mesmas sejam atendidas convenientemente. Este ano, o número de professores foi aumentado para cem, contra 76 no último exercício. Destarte ficaram providos vários pontos do município, cujas populações, trabalhadoras e pacatas, viam os filhos crescer à míngua dos indispensáveis conhecimentos teóricos para a vida de amanhã. A Inspetoria Escolar não tem poupado esforços para que todas as escolas disponham do material necessário, além de não descuidar do ensino patriótico. Sobre este ponto, todas as aulas receberam bandeiras nacionais $\mathrm{e}$, nos dias de feriados, os respectivos professores fazem preleções aos alunos sobre a data que se comemora e sobre o lábaro da Pátria. Com o fito de incrementar a matrícula, a lei orçamentária para o corrente exercício estipula o prêmio de cinco mil réis para os alunos que ao lado da boa frequência demonstram real aproveitamento no fim do ano letivo. Esta medida tornará mais fácil a frequência, porquanto, ao menos em parte, contribuirá para facilitar os pais de família, que deixam de mandar os filhos à escola para não sentirem falta de seus braços nos tempos de colheita e servirá, além disso, para despertar o estímulo entre os alunos, que tido envidarão para receber o prêmio de bom cumprimento de seus deveres. Por intermédio de seus auxiliares, mantém a municipalidade uma fiscalização permanente e vigorosa das aulas, no que fiz respeito à higiene e boa acomodação das mesmas. Ultimamente, alguns núcleos coloniais têm doado à Intendência os terrenos e casas necessários ao ensino, sendo que já estão sendo organizados os campos agrícolas, onde os alunos receberão noções práticas de agricultura, aprendendo, assim, os nossos métodos de cultivo, que lhes farão abandonar o sistema rotineiro até agora seguido. Tendo os Conselheiros Municipais, em um louvável gesto de amor à Instrução, doado o subsídio que lhes competia para ser empregado na difusão do ensino, sabemos que o Dr. Intendente aplicará a respectiva verba subvencionando uma escola prática de comércio, que funcionará anexa à aula de mecanografia e datilografia, que a conhecida Casa Pratt, de Porto Alegre, abrirá em breve nesta cidade, sob a competente direção de uma professora diplomada no curso que a referida casa mantém naquela Capital. Nestas condições basta a boa vontade dos nossos chefes de família, especialmente dos distritos rurais para que a instrução seja ministrada convenientemente no município de Caxias. (JORNAL 'O Regional', 30/01/1926, capa) [grifos meus].

A despeito da propaganda e da evidência da posição do jornal como defensor das políticas empreendidas pela gestão de Gobbato, as principais estratégias foram evidenciadas, assim como os avanços obtidos pelas escolas municipais, em especial aquelas rurais. Chama atenção também a criação dos campos agrícolas, junto às escolas rurais que tinham como finalidade ensinar e incentivar práticas mais modernas de cultivo agrícola. Pensando na formação de Gobbato e nas características econômicas regionais, tinha muito sentido que tal empreendimento fosse estimulado. 
Outra evidência recorrente foi a valorização do ensino da catequese nas escolas públicas, bem como do ensino cívico, em especial com as datas comemorativas da Independência e da Proclamação da República. A realização dos exames finais ocorria mediante uma comissão examinadora externa tendo o Inspetor como responsável. A seguir, o registro do dia da aplicação dos exames finais na Aula Municipal Núcleo Louro com a professora Maria Busa Job que tinha 29 alunos matriculados em 1926, sendo 13 de sexo masculino e 16 do feminino. Consta que a frequência era de 27 alunos, sendo 12 do sexo masculino e 15 do sexo feminino.

Figura 2 - Exames realizados na Aula Municipal do Núcleo Louro, 1926

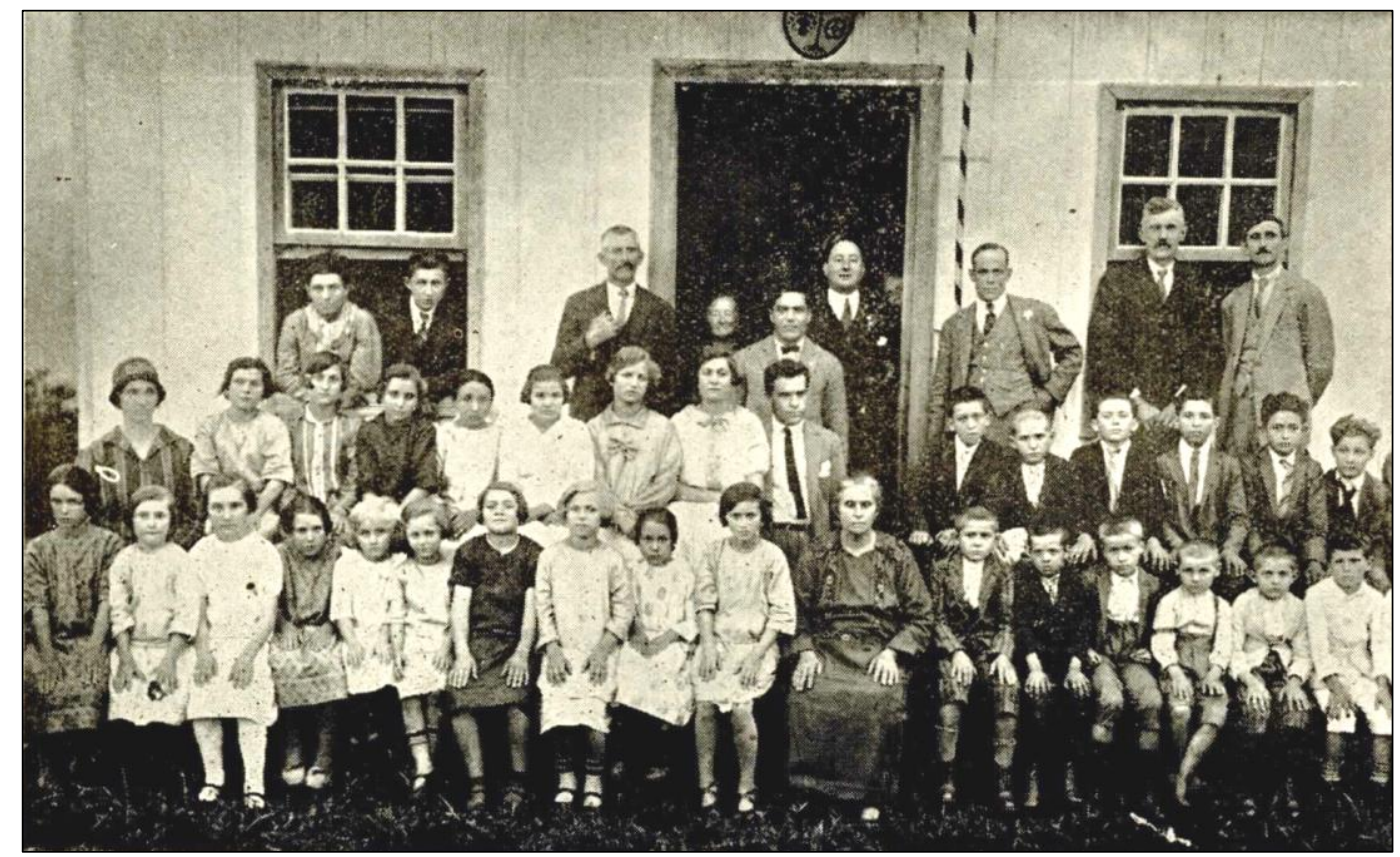

Fonte: RELATÓRIO, 1928, p. 52.

A realização dos exames finais reunia também familiares dos alunos e a maioria dos registros fotográficos das escolas são desse dia. Tradicionalmente, após os exames eram promovidos momentos de socialização com apresentação de poesias, cantos, teatros e trabalhos manuais dos alunos. Seguia-se com almoço ou jantar numa das famílias que residia próximo da escola. A figura 2 apresenta a aula rural da professora Maria Busa Job e chama atenção o modo como os alunos estão dispostos, separados por sexo, os adultos que aparecem ao fundo são os familiares, além dos integrantes da comissão examinadora. O prédio da aula, em madeira, tem fixado sobre a porta o brasão municipal de Caxias, também criado e distribuído durante a administração de Gobbato.

Como forma de 'balanço' dos trabalhos efetivados ao longo do ano de 1926 e em comemoração ao segundo ano de governo, Celeste Gobbato apresentou uma síntese das condições do município, afirmando que no campo escolar os avanços eram evidentes e lisonjeiros:

Coerente ainda com o programa administrativo que nos impusemos, a instrução pública continua merecendo nossa melhor atenção. O serviço de estatística visando também esclarecimentos que aproveitassem a instrução pública, patenteou a boa localização das escolas, revelando o que é de muita importância que nos lugares de maior aglomeração infantil, uma escola se encontra pronta a difundir os ensinamentos de primeiras letras. Em um total de 6.383 crianças na segunda infância, estão matriculados nas diversas escolas 5.586 o que representa uma porcentagem muito superior à verificada no conjunto do Estado. 


\begin{abstract}
Desses 5.586 alunos matriculados, pertencem às escolas municipais 2.825. [...] fornecerá um futuro próximo os meios indispensáveis para que o cidadão possa dignamente exercer a sua missão, consagrando a sua existência ao serviço da família, da pátria e da humanidade. Se do total da população 87,5 por cento está matriculada em escolas diversas, admitimos também essas organizações particulares, leigas e religiosas, que numa competição digna, concorrem para a alfabetização, graças ao regime do ensino livre, amplamente assegurado pela nossa carta constitucional. Seja-nos lícito lembrar, sem preocupações egoístas que rio-grandense de coração, ufano-me em ver este glorioso Estado na vanguarda dos mais alfabetizados da Federação Brasileira. (JORNAL 'O Regional', 16/10/1926, capa).
\end{abstract}

Como projeto de escolarização, além do empenho em promover as escolas municipais - ampliando a oferta, melhorando a frequência e garantindo maior aproveitamento - nas áreas rurais, a preocupação de Gobbato foi com a abertura de um ginásio, solicitando ajuda para tal intento de Mussolini, através de correspondência enviada em 06/12/1927 em que buscava angariar apoio para que os salesianos instalassem um ginásio em Caxias, em terreno doado pela municipalidade. O desejo era "fazer recordar as virtudes do povo italiano e fazer conservar a língua dos pais a esta juventude que, brasileira por nascimento, não desdenha, mas, antes, se sente orgulhosa de descender da estirpe italiana" (RECH e LUCHESE, 2018). O encaminhamento não surtiu o efeito desejado, e em 1928, o terreno foi entregue a Congregazione di San Giuseppe, que instalou o Colégio Murialdo. Outro projeto, considerado prioritário para Gobbato em sua gestão foi o Patronato Agrícola.

\title{
2. Ensino agrícola aos 'menores desvalidos': o Patronato Agrícola ${ }^{14}$
}

A gênese dos patronatos agrícolas no contexto brasileiro, remete, com relação ao marco legal, ao Decreto 12.893 de 28 de fevereiro de 1918 que autorizava a criação de patronatos agrícolas pelo Ministério da Agricultura ${ }^{15}$ e ao Decreto 13.706 de 25 de julho de 1919 que estabelecia nova organização aos patronatos agrícolas ${ }^{16}$ afirmando como fins dessas instituições, atender exclusivamente "classes pobres, [que] visam a educação moral, cívica, física e profissional de menores desvalidos, e daqueles que, por insuficiência da capacidade de educação na família, forem postos, por quem de direito, a disposição do Ministério da Agricultura, Industria e Commercio", além disso, afirmava que eram instituições voltadas para "assistência, proteção e tutela moral dos menores" promovendo o "trabalho agrícola, sem outro intuito que não o de utilizar sua ação educativa e regeneradora, com o fim de os dirigir e orientar, até incorporá-los no meio rural" (DECRETO 13.706 de 25/07/1919). Uma educação para os pobres, tornando-os úteis e produtivos, "conformação da força de trabalho, ou seja, preparar o trabalhador do campo para saber obedecer e produzir a partir de práticas embasadas na modernidade agrícola" analisa Vicente (2010, p.32).

No caso de Caxias, a primeira experiência de organização de patronato agrícola foi aquele aberto junto à Escola Industrial Elementar, criada em 1918, parceria da municipalidade com a Faculdade de Engenharia de Porto Alegre. Conforme estudo de Tisott (2017, p. 130), a

\footnotetext{
${ }^{14}$ Esse é um tema que merece uma pesquisa mais aprofundada que está por ser escrita. Na extensão desse artigo são apresentados apenas alguns elementos do seu processo histórico.

${ }^{15}$ DECRETO 12.893 de 28 de fevereiro de 1918. "Autoriza o Ministro da Agricultura a criar patronatos agrícolas, para educação de menores desvalidos, nos postos zootécnicos, fazendas-modelo de criação, núcleos coloniais e outros estabelecimentos do Ministério" (disponível em http://www2.camara.leg.br/legin/fed/ decret/1910-1919/decreto-1289328-fevereiro-1918-507076-publicacaooriginal-1-pe.html acesso em 02/02/2018).

${ }^{16}$ DECRETO 13.706 de 25 de julho de 1919. "Dava nova organização aos Patronatos Agrícolas". (disponível em http://www2.camara.leg.br/legin/fed/decret/1910-1919/decreto-13706-25-julho-1919-521010-republicacao95833-pe.html acesso em 02/02/2018).
} 
Escola Industrial Elementar "incorporou aos seus fazeres o ensino agrícola e práticas de assistência social voltadas às crianças que não tinham garantidas condições de vida as quais lhes permitissem usufruir dos benefícios da modernidade." Sob o título "Patronato Agrícola" o jornal O Brasil noticiava em sua capa, aos dez de abril de 1920 que:

A Escola de Engenharia de Porto Alegre deve inaugurar por esses dias, anexo à Escola Industrial desta cidade, um patronato para vinte menores desvalidos. Esse patronato ministrará instrução primária e agrícola e receberá, além dos menores internos, certo número de alunos externos. Para o desenvolvimento da nova instalação a Escola pediu à Intendência a concessão do resto do terreno onde está sendo construído o edifício para a instalação definitiva da Escola Industrial (JORNAL O BRASIL, 10/04/1920, capa).

A experiência proliferou em número de estudantes, tornando-se superior aqueles vinculados à agricultura em relação aos que se profissionalizavam para a indústria. Conforme Tissot (2017, p. 131), “depois de 1921, quando o patronato já abarcava cerca de um terço dos 72 estudantes da escola, as matrículas tiveram uma grande redução. Em 1922, apenas 41 crianças e jovens aparecem nos registros, sendo 20 deles internos do patronato. A mesma quantidade de internos foi registrada em 1923, quando o total de matrículas foi de 35 estudantes". As atividades foram encerradas em 1924, meses antes da posse de Gobbato.

Ao assumir, Gobbato mencionava a importância de iniciativas que valorizassem a agricultura e, em especial o ensino de técnicas modernas de cultivo. Afinal, essa era sua especialidade e, de certo modo, encontrava eco nas características regionais. Assim, a ideia de criação do Patronato Agrícola foi fomentada e ganhou força. Mas o maior desafio era o investimento financeiro para viabilizar tal intento. O caminho foi mobilizar famílias e lideranças, assim

a taxa pró-Patronato Agrícola está dando ótimos resultados e a população se interessa pela realização desse desideratum, como tereis notado pelas festas organizadas com o fito de conseguir recursos para o edifício que já projetamos, e que levaremos a termo no exercício vindouro, se ficar aprovado, durante vossas reuniões, a parte do projeto de orçamento da receita e da despesa para 1928 que, tive a honra de apresentar-vos (RELATÓRIO, 1928a, p. 03).

Na continuidade do relatório, o Intendente agradecia aos integrantes da Comissão PróPatronato afirmando "meus melhores agradecimentos às distintas pessoas que formaram a Comissão Pró-Patronato Agrícola, constituída pelos Srs. Presidente, Demétrio Niederauer, membros, D. Sylvia Braghirolli, D. Umbelina Faccioli ${ }^{17}$ e D. Egyde Spinato que não pouparam tempo nem esforços para trabalharem em prol deste Instituto" (RELATÓRIO, 1928a, p.04). A esses nomes somaram-se outros e foram diversas as atividades sociais criadas em prol do levantamento de fundos para o patronato.

Para sensibilizar os munícipes, foram divulgadas reportagens, apelos e notas informando os objetivos do patronato e o avanço que a Comissão Pró-Patronato obtinha. Recorrente é o argumento de educar para 'salvar' os menores desvalidos e torna-los 'uteis' à sociedade, como no recorte a seguir, extraído de reportagem de capa do jornal O Regional:

\footnotetext{
${ }^{17}$ Umbelina Faccioli casou em 1930 com o italiano Carlos Arpini com quem teve dois filhos: Sérgio Fernando e Ivan Bento Arpini. Integrou a Confraria Nossa Senhora do Carmo. Faleceu em 22 de maio de 1956 (JORNAL PIONEIRO, 18/02/1960, p.11).
} 
Menores em idade escolar, ao invés de se entregarem aos primeiros chamados do vício que, mais tarde, os levará facilmente à prisão e ao suicídio, serão recolhidos àquele instituto de proteção, onde, além de rudimentares princípios de educação moral e intelectual, receberão ensinamentos práticos e teóricos da vida agrícola, aprendendo a abandonar os métodos caducos e a seguir os novos e adiantados processos de cultivo da terra (Jornal O Regional, 16/04/1927, capa).

A junção de esforços resultou na construção. Em terreno do município, o prédio que abrigaria o Patronato foi projetado pelo italiano Luigi Valiera ${ }^{18}$ e inaugurado por Getúlio Vargas aos 22 de abril de 1928. E iniciou suas atividades em agosto daquele ano. Observe-se nas figuras a seguir dois momentos da construção do prédio entre os anos de 1927 e 1928 e, depois, o prédio pronto (figura 4):

Figura 3 - Duas fases da construção do Patronato Agrícola, Caxias, 1927/1928
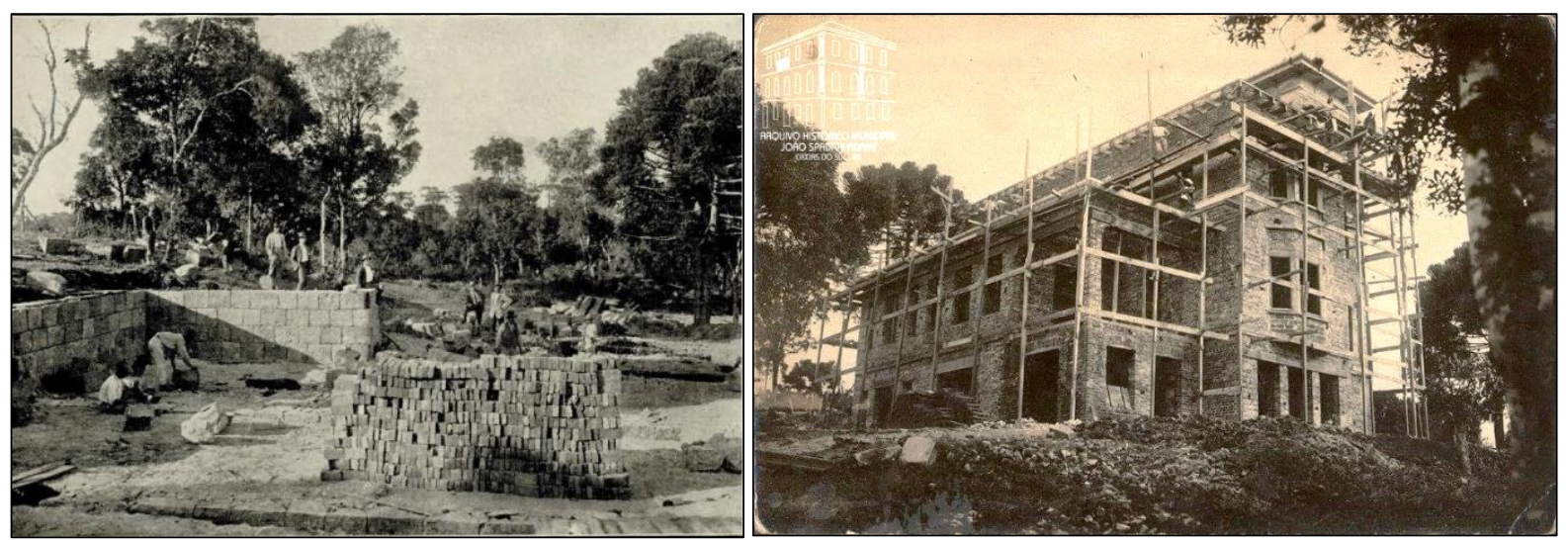

Fonte: RELATÓRIO, 1928a, p. 111; STJA3017, autoria não identificada, acervo do Arquivo Histórico Municipal João Spadari Adami.

Figura 4 - Vista do Patronato Agrícola ‘Celeste Gobbato' em dois momentos: na conclusão da obra (1928) e em dia de neve (1942)
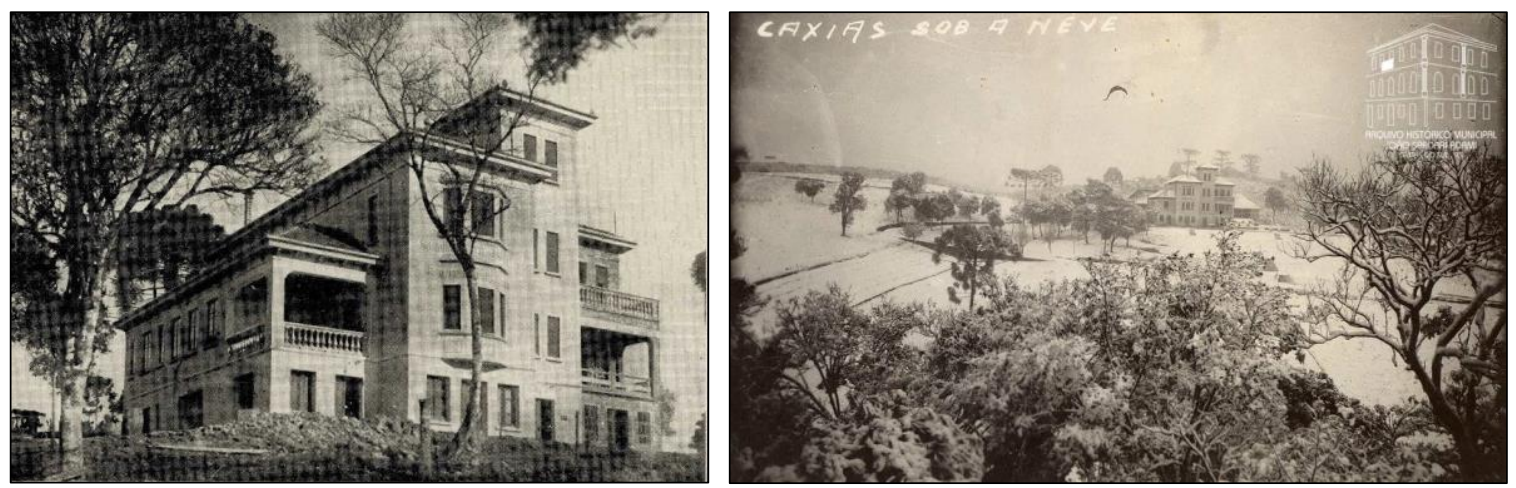

Fonte: Patronato Agrícola após conclusão das obras. RELATÓRIO, 1928, p. 76; Patronato Agrícola em dia de neve. JSA1022, autoria não identificada, Arquivo Histórico Municipal João Spadari Adami.

\footnotetext{
${ }^{18}$ Luigi Valiera era arquiteto. Em 1917 há registros de que tinha escritório em conjunto com Pianca, engenheiro civil em Porto Alegre. Em março de 1918 mudou-se com a família para Caxias, onde estabeleceu residência.
} 
$\mathrm{Na}$ figura 4, a primeira fotografia registra o prédio pronto, um pouco antes da inauguração, quando seria denominado Patronato Agrícola Celeste Gobbato e a outra fotografia, vista do prédio do Patronato em 1942, quando já tinha sido desativado. Cabe ressaltar que o prédio permanece até a atualidade.

Pelo Ato $\mathrm{n}^{\circ} 122$, de 5 de outubro de 1928, poucos dias antes do encerramento de seu mandato, Celeste Gobbato assinou o regulamento do Patronato Agrícola que estava em consonância com a legislação federal. Textualmente, estabelecia em seu capítulo I:

\section{Capitulo I - Seu fim}

Art. $1^{\circ}$. - O Patronato Agrícola Municipal será exclusivamente destinado as classes pobres, e visa a educação moral, física, cívica e profissional de menores desvalidos que forem internados.

Art. $2^{\circ}$. - O Patronato Agrícola constitui em seu conjunto, um instituto de assistência, proteção e tutela moral dos menores, recorrendo para esse efeito ao trabalho agrícola, sem outro intuito que não o de utilizar sua ação educativa como o fim de os dirigir e orientar até incorporá-los no meio rural (LIVRO DE ATAS do Conselho Municipal. Livro 06, 1928).

Já em seu segundo capítulo prescrevia que o ensino a ser ministrado seria "intuitivo, prático e limitado a condição do agricultor ou do trabalhador rural, compreendendo noções rudimentares de agricultura, em seus diferentes ramos" (LIVRO DE ATAS do Conselho Municipal. Livro 06, 1928). A sustentabilidade financeira da instituição, no entanto, foi um dos pontos controversos e que causou maior apreensão. Em sessão extraordinária de 16 de abril de 1928 foi aprovada a Lei $n^{\circ} 84$, depois sancionada pelo intendente Celeste Gobbato. A legislação previa que

O Conselho Municipal de Caxias, no uso das atribuições que lhe confere a Lei Orgânica, decreta: Art. $1^{\circ}$ ) Fica concedido, durante o prazo de dez anos, a contar do exercício financeiro de 1929, ao Patronato Agrícola Municipal desta cidade, destinado à educação gratuita dos meninos pobres, um auxílio anual equivalente ao quantitativo da arrecadação anual da taxa especial Pró-Patronato Agrícola Municipal, de 5\%, já em vigor, e aprovada na lei de orçamento para 1928. Parágrafo único: Fica garantido esse auxílio ainda mesmo que a taxa referida sofra diminuição ou seja suprimida. Art. $2^{\circ}$ ) $\mathrm{O}$ quantitativo da arrecadação anual será, sem desconto algum, entregue à medida que for arrecadada, mensalmente, à direção do Patronato Agrícola. Art. $3^{\circ}$ ) Uma regulamentação especial determinará o modo de prestação de contas do Patronato para com a Municipalidade, bem como as relações desta para com aquele, que terá, administrativamente, caráter autônomo. Art. $4^{\circ}$ ) A taxa Patronato Agrícola será aplicada: a) ao prosseguimento das construções exigidas pelo desenvolvimento do referido Instituto; b) a complementar e a melhorar as instalações; c) à liquidação das responsabilidades contraídas e futuras, avalizadas pelo Governo Municipal; d) custeio do Patronato, que será uma Escola Prática de Agricultura, para 30 alunos, que serão efetivos dentro de três anos, de ensino gratuito e com internato. Art. $5^{\circ}$ ) As matrículas serão concedidas pelo Intendente Municipal, ficando os alunos subordinados ao Regulamento que for expedido. Todos os meninos deverão ter a residência mínima de dez anos deste município. Art. $6^{\circ}$ ) O pessoal do Patronato, diaristas, técnicos, etc. serão de nomeação do Intendente Municipal, com a indicação da direção do Patronato. [...]" (LIVRO DE ATAS do Conselho Municipal, Livro 6, p. 107 e 108). 
Outra normativa, Lei $n^{\circ} 89$ de $02 / 07 / 1928$, regulamentou o modo de prestação de contas do Patronato para o período previsto na Lei $\mathrm{n}^{\circ} 84$, ou seja, por dez anos. A comissão de prestação de contas seria formada pelo presidente do Conselho Escolar e outros dois membros do mesmo, ficando - Presidente e vice, quando houvesse, do Patronato - responsáveis pela prestação de contas, com receitas e despesas. A comissão de contas, averiguando o apresentado, aprovaria ou não. O presidente do Patronato tinha mandato de três anos, podendo ser reconduzido. Ao final do mandato poderia indicar um substituto. Previa que o primeiro Presidente seria nomeado pelo intendente e que o Presidente do Patronato juntamente com o Diretor faria a assinatura dos cheques e de outros pagamentos/recebimentos do Patronato (LIVRO DE ATAS do Conselho Municipal, Livro 6, p. 122 e 123).

Como presidente do Patronato foi nomeado João Issler e como diretor, o agrônomo Salvador Petrucci, que também ocupava o cargo de Inspetor Escolar do município. O professor Firmino Bonett foi nomeado como auxiliar. O Patronato foi defendido pela administração municipal como uma obra patriótica, pois o intuito do ensino profissionalizante da agricultura somado à expansão dos conhecimentos de técnicas mais modernas de cultivo, fascinavam Gobbato e muitos de seus apoiadores.

A chamada para as matrículas no Patronato foi divulgada, mas os críticos já pronunciavam o custo elevado para a municipalidade com benefícios reduzidos a poucos jovens que seriam efetivamente atendidos. De toda forma, a chamada para a matrícula de estudantes publicado em fins de 1928 afirmava:

Figura 5 - Recorte da chamada para matrículas ao Patronato Agrícola, $1928^{19}$

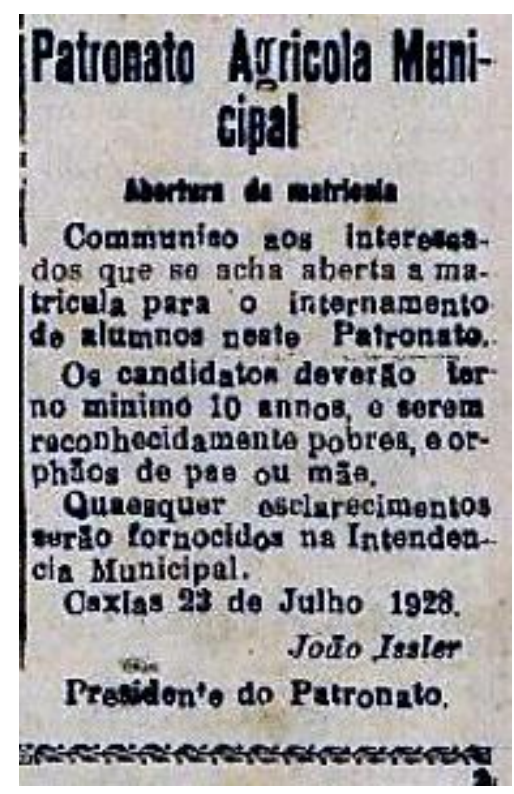

Fonte: JORNAL O Regional, 23/07/1928, p. 02.

Os primeiros internos do Patronato foram matriculados em 1928 num total de 12, constituído por meninos alguns órfãos de pai e mãe, outros de apenas um dos genitores. No quadro 6, conforme informações apresentadas no Relatório do Intendente Gobbato (1928b), foram matriculados os seguintes alunos:

\footnotetext{
19 Transcrição: Patronato Agrícola Municipal. Abertura da matrícula. Comunico aos interessados que se acha aberta a matricula para o internamento de alunos neste Patronato. Os candidatos deverão ter no mínimo 10 anos, e serem reconhecidamente pobres e órfãos de pai ou mãe. Quaisquer esclarecimentos serão fornecidos na Intendência Municipal. Caxias, 23 de julho de 1928. João Issler. Presidente do Patronato.
} 
Quadro 6 - Primeiros estudantes do Patronato Agrícola, 1928

\begin{tabular}{|l|l|}
\hline \multicolumn{1}{|c|}{ Menor } & \multicolumn{1}{c|}{ Filiação } \\
\hline Noé Barbosa Blum ${ }^{20}$ & Leon Blum (falecido) e Benta Barboza Blum \\
\hline Demetrio Luiz Damaciano & Maximiliano José (falecido) e Maria B. Fogaça \\
\hline Francellino da Silva Miranda & Adão Alves de Miranda (falecido) e Gasparina Nunes de Miranda \\
\hline Mauro Mendes Totta & Valdevino Mendes Totta (falecido) e Ritta de A. Totta \\
\hline Danillo C. Fabbris & Adolpho Fabbris (falecido)E e Thereza Chiumenti Fabbris \\
\hline Waldomiro Pereira & Miguel Pereira (falecido) e Amelia Vieira Lima \\
\hline Constantino X. Oliveira & João Alves de Oliveira e Alzira Soares de Oliveira (ambos falecidos) \\
\hline Clemente Camillo Silva & Francisco Silva e Amalia Silva (ambos falecidos) \\
\hline Adelmar Scotti & Angelo Scorri e Henriqueta Scotti (falecida) \\
\hline Arthur Pergher & Adolpho Pergher e Dantina Boccardi Pergher \\
\hline Eugenio Dal Ri Crippa & Filho de Arquinto Dal Ri Crippa (falecido) e Rosa Dal Ri Crippa \\
\hline João Canuto Settin & Angelo Settin (falecido) e Amelia Canuto Settin \\
\hline
\end{tabular}

Fonte: RELATÓRIO, 1928b, p. 97 e 98.

Não foi possível perscrutar os percursos dos internos e o tempo de permanência no Patronato. Mas as atividades iniciaram em 01 de agosto de 1928 e, pelo noticiado tinham sido acolhidos apenas 10 alunos que estavam "otimamente acomodados, com quartos amplos e ventilados, roupas e mantimentos excelentes, além de receberem todos os confortos necessários ao bom êxito do estudo que lhes é ministrado naquele próprio municipal" (JORNAL O Regional, 13/08/1928, capa). Foi possível saber que as aulas eram divididas em teóricas e práticas, sendo que as últimas eram realizadas junto aos viveiros do próprio Patronato. A ênfase prática na aprendizagem dos "modernos métodos de cultivo, preparando a lavoura e haurindo ensinamentos básicos indispensáveis para as agruras da vida" (JORNAL O Regional, 13/08/1928, capa). Mas é necessário que se reconheça que a abertura do Patronato foi acompanhada de críticas pelas despesas que a municipalidade tinha com sua manutenção. Ademais, o Intendente Thomás Beltrão, que substituiu Gobbato no poder municipal, já nos primeiros meses avaliou como insustentável manter o Patronato. A número de internos entre os anos de 1928 e 1934, último ano de seu funcionamento, variou entre dez e quinze estudantes. Na figura 6 a fotografia de uma das turmas de internos do Patronato:

Figura 6 - Meninos internos do Patronato Agrícola, década de 1930

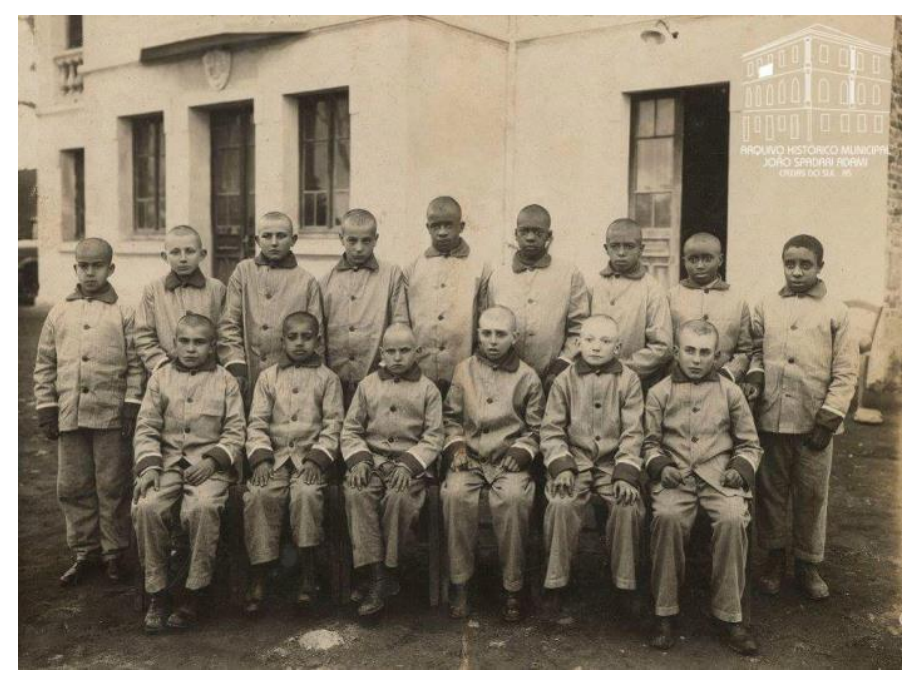

Fonte: STJB0046, autoria não identificada, acervo do Arquivo Histórico Municipal João Spadari Adami.

${ }^{20}$ Tornou-se policial em Caxias conforme noticiado "regressou de São Paulo, duma viagem de interesses industriais, o Sr. Noé Blum, alto funcionário da polícia local” (JORNAL Pioneiro, 03/03/1951, p.04). 
Uniformizados, rigidamente colocados e posicionados, o olhar da maioria desses meninos nos faz pensar que estão tristes. Quais as culturas vividas no interior dessa instituição? Como eram ensinados? Que práticas e que saberes eram privilegiados? Tinham contato com os familiares? Em que momentos? Muitos questionamentos emergem sobre o tema e um olhar investigativo para o interior da instituição e seus sujeitos escolares é tema de pesquisa a ser realizada. Em reportagem do Jornal Pioneiro, em 1990, foi publicado um breve indício desse cotidiano, com a memória de um dos ex-alunos do Patronato, Arthur Scalabrin Filho que permaneceu como interno da escola.

Integrando uma das primeiras turmas que estudaram no Antigo Patronato Agrícola encontramos o Sr. Arthur Scalabrin filho do italiano José Scalabrin e de Romilda Radaelli, natural de Encantado, RS. Arthur nascera em 27 de novembro de 1907. Teve como irmãos José Scalabrin Filho, Vitorio Scalabrin, Constantino e Ida. Entre eles a diferença de dois anos. Seu pai veio da Itália com seus avós e tios. Conseguiu comprar um terreno[...] (trecho da atual 18 do Forte) entre Marechal Floriano e Guia Lopes. Nascido em 18 de dezembro de 1883, José veio a falecer em sete de junho de 1918, num acidente ferroviário. Em 1928 morre também Romilda. Depois desse fato, Arthur Scalabrin ingressa no Patronato Agrícola de Caxias do Sul, onde permaneceu por dois anos. Sua rotina diária consistia em tomar café e dirigir-se junto com os companheiros para a roça, onde plantavam trigo e trabalhavam na horta. Na parte da tarde frequentavam as aulas ministradas pelo diretor da instituição. Somente os alunos mais velhos frequentavam a carpintaria. Muitos internos fugiam do Patronato. Quando retornavam, recapturados, recebiam castigos que incluía a palmatória e o isolamento dos demais. Somente nos finais de semana, quando saiam para visitar os parentes, lhes era permitido o uso do uniforme. Todos, indistintamente, tinham o cabelo raspado para evitar surtos de piolhos. Arthur ainda conta que nos últimos anos de existência do Patronato faltava comida e só tinha feijão. Por isso os internos eram obrigados a sair para o mato para buscar comida (pinhão, frutas...) (JORNAL Pioneiro, 03 e 04/02/1990, p.06).

É possível que os internos tenham representado a experiência vivida no Patronato de modos distintos, mas a função assumida pela instituição e o papel de 'salvar' os menores desvalidos merece ainda maior aprofundamento.

\section{Considerações finais}

Gobbato assumiu a intendência de Caxias como candidato do PRR, mas tendo obtido apoio da Igreja Católica e de outros grupos importantes localmente. Como intendente da conciliação, o projeto de escolarização fez parte de suas ações. É mister concluir lembrando que a administração municipal de Caxias aplicava $10 \%$ da arrecadação na escolarização, o que distingue a gestão por ser um dos maiores índices investidos por municípios nessa época.

Os investimentos voltaram-se para a expansão do número de escolas, ampliando e melhorando as condições de ensino com provimento de alguns materiais essenciais para as escolas, regulamentando a seleção de professores e oferecendo cursos de aperfeiçoamento. Algumas aulas rurais passaram a funcionar em dois turnos, o que diminuiu o número de alunos e melhorou as condições de ensino. Orquestrado pela Inspetoria Escolar, foram feitos ajustes no calendário escolar, criados incentivos para que os pais enviassem os filhos para a escola, 
melhorando a frequência e foram instituídos campos escolares para a prática agrícola em diversas escolas. Como hábil negociador, Gobbato obteve um dos dois grupos rurais agrícolas constituídos no RS nessa época e obteve ampliação do número de escolas subvencionadas pelo estado no município. Além disso, investiu na construção do prédio para o Patronato Agrícola, que entrou em funcionamento ao final de seu mandato. Os críticos de Gobbato consideraram um investimento muito elevado para a municipalidade, contrastando com o baixo retorno obtido, mediante o número de beneficiados.

Ao investigar as estratégias de Gobbato e de seus apoiadores em prol da escolarização, foi possível perceber nuances de como "projetaram, idealizaram e puseram em marcha programas de educação e instrução, num quadro de complemento da ação estatal, mas frequentemente também levando a sua autonomia até à criação de uma oferta educativa própria que incluía a rede escolar, os professores, os cursos profissionais" (MAGALHÃES, 2015, p.45), como foi o caso do Patronato Agrícola e Escola do Conselho Municipal.

Gobbato não pode ser pensado como um administrador isolado em seu momento histórico, pois outros empenharam-se em alcançar metas próximas, mas talvez não contassem com o respaldo por ele obtido. Gobbato pode contar com o Conselho Municipal e as comissões do Pró-Caxias, mas também com as comunidades rurais que manifestaram apreço ao modo como ele administrou, além da Igreja e outras lideranças locais (caso de comerciantes, empresários...). A preocupação em expandir as escolas, melhorar a frequência e promover entre os estudantes o conhecimento de técnicas modernas de agricultura, com o plantio de sementes selecionadas, constituiu-se num diferencial que como afirma Gonçalves Neto (2015, p. 32) foi "estabelecendo uma identidade própria ao ensino em cada cidade, de acordo com as prescrições singulares de cada localidade".

\section{Referências}

CALVINO, Ítalo. As cidades invisíveis. Rio de Janeiro: O Globo; São Paulo: Folha de São Paulo, 2003.

CARVAlHO. Carlos Henrique de e CARVAlHO, Luciana B. de O. Bar de. O município pedagógico e a descentralização do ensino no Brasil: a educação em Minas Gerais no início da República (1889 - 1906). In: Revista Ibero-americana de estudos em Educação. Araraquara, SP, Brasil, v.5, nº 2, 2010, p. $01-17$.

CORRESPONDÊNCIAS. Fundo Educação e Cultura. Códice 06.01.02, Diretoria de Instrução Pública. Arquivo Histórico Municipal João Spadari Adami.

CORRESPONDÊNCIAS. Fundo Educação e Cultura. Códice 06.01.03. Arquivo Histórico Municipal João Spadari Adami.

DECRETO 12.893 de 28 de fevereiro de 1918, disponível em http://www2.camara.leg.br/legin/fed/decret/1910-1919/decreto-12893-28-fevereiro-1918507076-publicacaooriginal-1-pe.html acesso em 02/02/2018.

DECRETO 13.706 de 25 de julho de 1919, disponível em http://www2.camara.leg.br/legin/fed/decret/1910-1919/decreto-13706-25-julho-1919-521010republicacao-95833-pe.html acesso em 02/02/2018.

FERNANDES, Cassiane C. Uma história do Grupo Escolar Farroupilha: sujeitos e práticas escolares (Farroupilha/RS, 1927-1949). 217fl. Dissertação (Mestrado) - Universidade de Caxias do Sul, Programa de Pós-Graduação em Educação, 2015. 
FOTOGRAFIAS do acervo do Arquivo Histórico Municipal João Spadari Adami, Caxias do Sul, RS.

GINZBURG, Carlo. Mitos, emblemas e sinais. Morfologia e História. São Paulo: Companhia das Letras, 1989.

GIRON. Loraine S. As Sombras do Littorio: o fascismo no Rio Grande do Sul. $2^{\mathrm{a}}$ ed. Caxias do Sul, 2017.

GONÇALVES NETO, Wenceslau. Repensando a História da Educação brasileira na Primeira República: o município pedagógico como categoria de análise. In: GONÇALVES NETO, Wenceslau e CARVALHO, Carlos Henrique de (org.). Ação municipal e Educação na Primeira República no Brasil. Belo Horizonte: Mazza Edições, 2015, p. 19 - 35.

I MUNICIPI DELLA COLONIA italiana nello stato di Rio Grande do Sul (Brasile) - Bento Gonçalves - 1924 a 1928.

JORNAL 'A Federação', órgão do Partido Republicano. Diretor de redação: Othelo Rosa. Gerente: Nabor Moura de Azevedo. Porto Alegre, ano XLIII, nº 105, 06/05/1925.

JORNAL 'Correio Colonial', órgão dos interesses da região colonial do Estado. Diretorgerente: Ulysses João Castagna. Redatores: Remigio Ducchini e Julio Mottin. Ano I, $\mathrm{n}^{\mathrm{o}} 12$, 07/03/1925, p. 05.

JORNAL 'Correio Colonial', órgão dos interesses da região colonial do Estado. Diretorgerente: Ulysses João Castagna. Redatores: Remigio Ducchini e Julio Mottin. Ano I, ${ }^{\circ}{ }^{13}$, 14/03/1925, p. 02.

JORNAL 'Correio Colonial', órgão dos interesses da região colonial do Estado. Diretorgerente: Ulysses João Castagna. Redatores: Remigio Ducchini e Julio Mottin. Ano I, ${ }^{\circ}$ 21, 09/05/1925, p. 02.

JORNAL 'Correio Colonial', órgão dos interesses da região colonial do Estado. Diretorgerente: Ulysses João Castagna. Redatores: Remigio Ducchini e Julio Mottin. Ano I, $\mathrm{n}^{\mathrm{o}} 31$, 25/07/1925, p. 02.

JORNAL 'O Regional', órgão dos interesses da região colonial do Estado. Publicado aos sábados. Diretor Luiz Miranda, Gerente José Balen. Ano I, nº 11, Caxias, 27/03/1926.

JORNAL 'O Regional', órgão dos interesses da região colonial do Estado. Publicado aos sábados. Diretor Luiz Miranda, Gerente José Balen. Ano I, nº 40, Caxias, 16/10/1926.

JORNAL 'O Regional', órgão dos interesses da região colonial do Estado. Publicado aos sábados. Diretor Luiz Miranda, Gerente José Balen. Ano I, nº 4, Caxias, 30/01/1926.

JORNAL 'O Regional', órgão dos interesses da região colonial do Estado. Publicado aos sábados. Diretor Luiz Miranda, Gerente José Balen. Ano II, nº 16, Caxias, 16/04/1927.

JORNAL 'O Regional', órgão dos interesses da região colonial do Estado. Publicado aos sábados. Diretor Luiz Miranda, Gerente José Balen. Ano III, nº 32, Caxias, 13/08/1928. 
JORNAL O Brasil. Órgão do Partido Republicano. Proprietário Américo Mendes. Redatores Agnello Cavalcanti e Demétrio Niederauer. Ano XIII. Publicado aos sábados à tarde. 10/04/1920, p. 01.

JORNAL Pioneiro. Diretor Isidoro D. Moretto, Diretor e redator Mario Gardelin. Ano III, $\mathrm{n}^{\circ}$ 21, 03/03/1951, p. 04.

JORNAL Pioneiro. Diretor Mario Rocha Netto. Ano XIII, nº 16, 20/02/1961, p. 11.

JORNAL Pioneiro. Patronato Agrícola. Ano 42, n 4.441, 03 e 04 de fevereiro de 1990. Encarte Sete Dias, p. 06.

LIVRO DE ATAS do Conselho Municipal. Livro 06, de 15/11/1921 a 01/11/1930. Arquivo Histórico Municipal João Spadari Adami, Caxias do Sul.

LUCHESE, Terciane Â. O processo escolar entre imigrantes no Rio Grande do Sul. Caxias do Sul, RS: EDUCS, 2015.

LUCHESE, Terciane Â. Em busca da escola pública: tensionamentos, iniciativas e processo de escolarização na Região Colonial Italiana, Rio Grande do Sul, Brasil. In: Cadernos de História da Educação. V. 11, nº 2, jul./dez. 2012, p. $667-679$.

LUCHESE, Terciane Â.; GRAZZIOTIN, Luciane S. Memórias de docentes leigas que atuaram no ensino rural da Região Colonial Italiana, Rio Grande do Sul (1930 - 1950). In: Educação e Pesquisa. São Paulo, v. 41, n. 02, p. 341-358, abr./jun. 2015.

LUCHESE, Terciane Â.; KREUTZ, L. Das escolas de improviso às escolas planejadas: um olhar sobre os espaços escolares da Região Colonial Italiana, Rio Grande do Sul. Revista Brasileira de História da Educação, v. 12, p. 45-76, 2012.

MACHADO, Maria A. Construindo uma Cidade: História de Caxias do Sul - 1875/1950. Caxias do Sul: Maneco Livraria \& Editora, 2001.

MAGALHÃES, Justino. O município liberal e a decisão política. In: GONÇALVES NETO, Wenceslau e CARVALHO, Carlos Henrique de (org.). Ação municipal e Educação na Primeira República no Brasil. Belo Horizonte: Mazza Edições, 2015, p. 37 - 46.

MONTEIRO, Katani. Entre o vinho e a política: uma biografia de Celeste Gobbato (1890 1958). Caxias do Sul, RS: EDUCS, 2016. Ebook disponível em https://www.ucs.br/site/midia/arquivos/ebook-entre-o-vinho.pdf acesso em 01/02/2018.

MORETTO, Paulina Soldatelli entrevistada por Cleodes Piazza Ribeiro em 08/01/1983. Transcrição de Tranquila Bambina Moresco Brando. In: Projeto Elementos Culturais das Antigas Colônias Italianas no nordeste do Rio Grande do Sul (ECIRS), Instituto de Memória Histórica e Cultural da Universidade de Caxias do Sul.

RECH, Gelson; LUCHESE, Terciane Â. Escolas italianas no Rio Grande do Sul: pesquisa e documentos. Caxias do Sul, RS: EDUCS, 2018 (no prelo).

REGISTRO DE Atos da Intendência Municipal (1924 - 1930). Fundo Educação e Cultura. Códice 01.01.01. Arquivo Histórico Municipal João Spadari Adami. 
RELA, Eliana. Nossa fé, nossa vitória. Igreja Católica, maçonaria e poder político na formação de Caxias do Sul. Caxias do Sul: EDUCS, 2004.

RELATÓRIO apresentado ao Conselho Municipal pelo Intendente Coronel J. Penna de Moraes na sessão ordinária em 22 de dezembro de 1923. Porto Alegre: Officinas Graphicas d’A Federação, 1924.

RELATÓRIO correspondente ao período administrativo de $1^{\circ}$ de janeiro a 31 de dezembro de 1926, apresentado ao Conselho Municipal pelo Intendente, Dr. Celeste Gobbato. Caxias: Livraria Mendes, 1928.

RELATÓRIO correspondente ao período administrativo de $1^{\circ}$ de janeiro a 30 de setembro de 1928, acompanhado de um resumo dos trabalhos realizados durante o quadriênio de 1924 1928 apresentado ao Conselho Municipal pelo Intendente, Dr. Celeste Gobbato. Porto Alegre: Centro da Boa Imprensa, 1928b.

RELATÓRIO correspondente ao período administrativo decorrido de 12 de outubro de 1924 a 31 de dezembro de 1925, apresentado ao Conselho Municipal pelo Intendente, Dr. Celeste Gobbato e Lei Orçamentária de Receita e Despesa e Autorizações ao Intendente para o exercício de 1926. Porto Alegre: Oficinas Gráficas da Escola de Engenharia de Porto Alegre, 1926.

RELATÓRIO correspondente ao período administrativo decorrido de $1^{\circ}$ de janeiro a 31 de dezembro de 1927, apresentado ao Conselho Municipal pelo Intendente, Dr. Celeste Gobbato. Caxias: Livraria Mendes, 1928a.

REVEL, Jacques (org.). Jogos de escalas. A experiência da microanálise. Rio de Janeiro: Editora Fundação Getúlio Vargas, 1998.

TISOTT, Ramon V. Formar trabalhadores, transformar a sociedade: o ensino industrial em 3 tempos (Caxias do Sul, 1901 - 1964). 231fl. Tese em História. Porto Alegre: Programa de PósGraduação em História, UFRGS, 2017.

VICENTE, Magda A. O Patronato Agrícola Visconde da Graça em Pelotas/RS (1923-1934): gênese e práticas educativas. 157fl. Pelotas: Programa de Pós-Graduação em Educação, UFPel, 2010 . 